\title{
SELECTED TECHNICAL SOLUTIONS IN CONSTRUCTION FOR ELDERLY PEOPLE IN POLAND
}

\begin{abstract}
A. K. NICAL ${ }^{1}$
This paper brings up the issue of population aging and its influence on designing and construction of buildings in Poland. It also touches the problem of adaptation of existing facilities to the needs of the elderly and the disabled. Moreover, current trends in Polish demographics and possible outlook for the next 45 years has been presented. The author presents the current legal state concerning rules and regulations on the aspects of adjusting the buildings and their parts to the needs of the disabled. Additionally, the dimensions and the areas of movement for the disabled as well as the primary functional and requirements for bathrooms have been described. In the next paragraph, a concept of Ambient Assisted Living with examples of sanitary equipment for use in residential buildings has been propose.
\end{abstract}

Keywords: ambient assisted living, elderly people, construction, demography

\section{INTRODUCTION}

The tendencies observed in Poland in changes of natural movement after the year 1989 have led to a substantial change in the demographic structure of the country.

The same as in case of Western Europe, the length of life has increased, mainly because of the improvement of living and social conditions. Unfortunately, a substantial decrease has been noticed in fertility as well as formation and durability of marriages. Additionally, the negative population trend is influenced by increasing migration.

\footnotetext{
${ }^{1}$ PhD., Eng., Warsaw University of Technology, Faculty of Civil Engineering, Al. Armii Ludowej 16, 00-637 Warsaw, Poland, e-mail: a.nical@il.pw.edu.pl
} 
Population processes defined as the second demographic transition are characterized by creating families in older age, relatively late period of maternity, decrease in marriage number and increase in the number of informal relationships. These processes are observed in Europe since the half of the 1960's and currently have a global character. The concept of "New demography of Europe" introduced by D. van de Kaa in 2003 not only means changes accompanying the processes of passage to modern reproduction, but also fixation of this process significantly below the straight of replacement of generations [7]. Low fertility (fertility factor equal to 1,5 or lower) with systematic extension of life and increase in the significance of migration leads to decrease of birthrate and, in consequence, to irreversible changes in the structure of population [6]. In effect, a disturbance in the relations between generations - persons in productive and older people - took place. These forecasts have been noticed already in the 1980's and 1990's, the remedy being propositions to shift the age of retirement and stimulation of professional activity for persons aged 50+ and 60+. Research conducted around the world shows that the share of $65+$ people will increase from $7 \%$ in the first decade of 21 st century to $16 \%$ in the year 2050 [4]. Despite the fact that in comparison to European Union Poland is still a relatively young country with a median in 2012 being 38.7 years, it can be said with a big dose of probability that the tendencies of society aging are irreversible. According to the newest Eurostat forecast (EuroPop 2013), after the year 2024 the share of people aged 65+ in the general structure of Poland will exceed $20 \%$ and reach $33 \%$ in 2060 [6], [8], [9], [10], [11], [12]. The consequence of these phenomena will be an increase in tax burden for professionally active people and a probable decrease in economical efficiency of pension systems. Further consequence will be a visible impoverishment of the retired and decrease of young and middle aged persons able to take care of the elderly. Additionally, uncertain economic and political situation in Central Eastern Europe lays a doubtful shadow on opening Polish Eastern borders and increase in migration which could lead to improvement [13], [14], [15], [16]. Bearing in mind aforementioned statements, attempts should be undertaken to solve the problem of society aging through development and implementation of concepts facilitating everyday chores for the elderly, especially increasing their autonomy, mobility and self-reliance. 


\section{ADAPTATION OF BUILDINGS FOR THE ELDERLY AND DISABLED PEOPLE IN POLAND}

\subsection{LEGAL STATUS}

The issues of adaptation of public buildings, multi-family residential buildings and collective residences for the disabled are regulated by Construction Law Statute of July 7 1994. In the point 3 the legislator placed an unequivocal and clear statement that necessary conditions for using public and residential buildings for the disabled, especially for those on wheelchairs should be created. Another document containing selected technical and construction regulations specifying conditions that buildings should be compliant with is Regulation of the Minister of Infrastructure of 12 April 2002 on the technical conditions that should be met by buildings and their location.

\subsection{BASIC DIMENSIONS AND MOVEMENT RANGES}

Due to various afflictions and types of disability (motor, visual, auditory, etc) there is no uniform definition describing disabled persons. Additionally, the abilities or psychophysical disabilities qualify the users of the space to more or less able groups [3]. That is why the data from Fig. 1 concerning the range of motion and dimensions are of general nature and concern the disabled on wheelchairs.
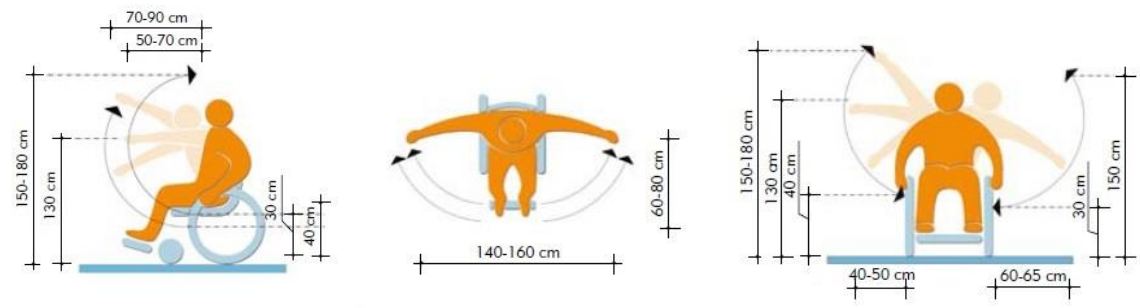

Fig. 1. Range of vertical and horizontal arm movement

For such persons, dysfunctions and restrictions of their organism are a problem as well as various adjuvant equipment. Paradoxically, persons with bigger disabilities having better equipment can be more able than people with lower level of disability [3]. Data concerning anthropometric abilities of persons with motor disability are thus averaged. It concerns most of the space's features such 
as e.g. height, plane of view, range of upper or lower limbs etc. For averaging the data additional problems arise because of the variety of wheelchairs - for persons using motorized equipment maneuver field and its dimensions (length, width) will be bigger than the norm. It concerns also the maneuver zone and range of arms, range of sight, eye's angle. When designing the object, it is the safest to assume individual parameters according to user's abilities and requirements. They have a significant influence on attaining safe amounts of space needed to move through living space, work or make use of the nearest environment.

\subsection{RoOMS}

Apart from accessible surroundings including streets, parking spaces, entrances, external stairs, ramps, driveways, vestibules, accesses, doors, lifts, windows, corridors, platforms, man lifts and internal stairs, it is important to ensure adequate safety, hygiene, and functionality measures inside the buildings. Bathroom is a place where a lot of accidents happen. While designing it, it is important to take into account the necessity of ensuring an adequate maneuver space for a wheelchair which should not be smaller that $150 \times 150 \mathrm{~cm}$ [8]. Moreover, separate bathroom and toilet are frequently seen in existing buildings. It is a significant impediment for the disabled and it is recommended to merge these two rooms.

Safety handles with circumference of 2 to $3.5 \mathrm{~cm}$ and $75-85 \mathrm{~cm}$ from the floor should be installed in the bathrooms. Due to lesser gripping abilities of elderly persons, it is recommended to install thicker handles with corrugated surface.

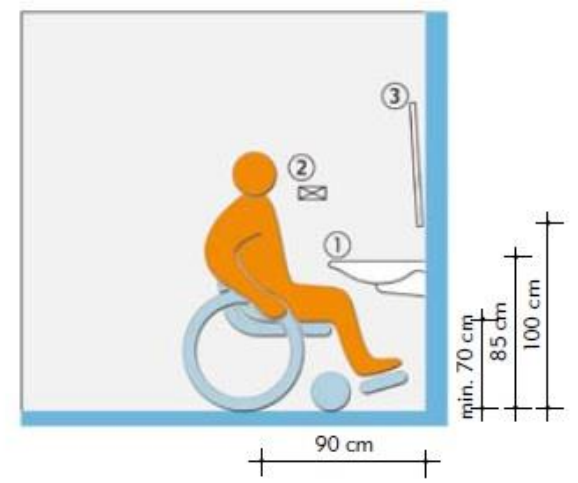

Fig. 2. Basic dimensional parameters of a bathroom, where: 1 - bathroom sink $\mathrm{h}=85 \mathrm{~cm} ; 2$ - wall socket with grounding $\mathrm{h}=80-110 \mathrm{~cm} ; 3$ - mirror rotated on a horizontal axis [3] 
Basic guidelines that a bathroom should additionally fulfill are:

- Non-slip surfaces (e.g. perforated mattresses and mats in the bathtub made of rubber or special kind of plastic),

- Optimal size of toilet bowl $45-50 \mathrm{~cm}$ (it would be most preferable that the height of the toilet bowl be approximately the height of the wheelchair, or use overlays),

- Automatic flush or a button placed on the side of the toilet bowl at the height of $100 \mathrm{~cm}$,

- Minimal size of the shower base $90 \times 90 \mathrm{~cm}$ with a $1-2 \%$ decline to the grate (it is recommended to supply the shower bases with openwork seats covered with pleasant to the touch vinyl with armrests and anti-slip surface),

- Height of the upper edge of the washbasin $85 \mathrm{~cm}$, free space over the washbasin $70 \mathrm{~cm}$,

- Minimal distance of the power outlets $60 \mathrm{~cm}$ from the source of water, height $40-110 \mathrm{~cm}$.

\section{AMBIENT ASSISTED LIVING}

\subsection{MAIn AsSumptions}

The aim of Ambient Assisted Living is the improvement of elderly persons' functioning conditions in the society by, among others, development of industrial technologies based on information and communications. In particular, AAL initiative assumes development and implementation innovative products, services and systems for the elderly which will ease their everyday chores. In effect, it is possible to reduce their social exclusion as well as costs of social and health care. The conception of AAL aims also to increase the engagement of elderly persons on the work market where their experience and knowledge is of high value.

\subsection{SELECTED TECHNICAL SOLUTIONS FOR SANITARY ROOMS}

Activities of Daily Living [17] performed by the elderly can be divided into two categories:

- Basic Activities of Daily Living (BADLs),

- Instrumental Activities of Daily Living (IADLs).

BADLs include personal hygiene, dressing up and down, eating, and moving around the living space using a wheelchair, crutches or other equipment including moving from the wheelchair to and from bed and toilet bowl [5], [9]. More demanding activities are called IADLs and are frequently not absolutely necessary to everyday living, but allow for more independent and comfortable living. 
They include: house work, ingesting medicines, shopping, dressing up, using the phone and other kinds of communication as well as using public transport [2]. Basic living activities are the basis to assess the independence of the elderly because they usually have to rely on help of their caretakers. According to their age, the intensity of required help is formed as follows (Fig. 3).

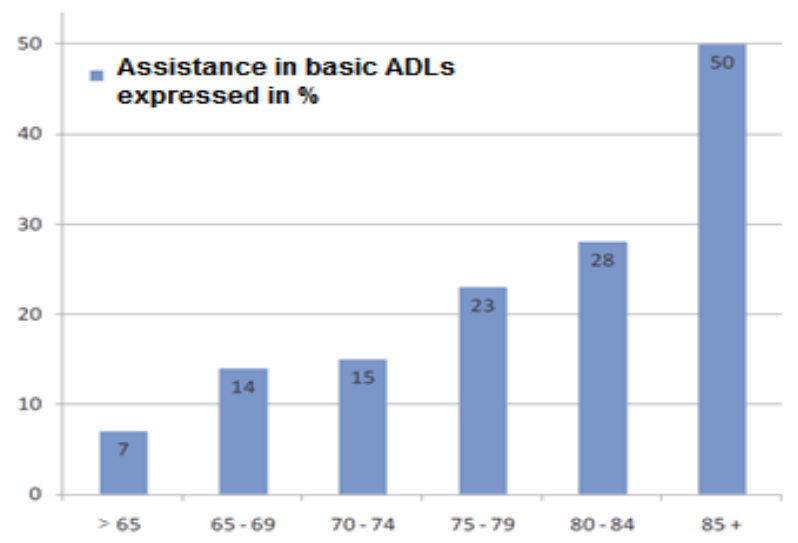

Fig. 3. Care dependency vs. age groups [1]

Performing the easiest home activities is very strenuous for elderly persons. The market offers currently a lot of technical solutions and support systems for them, e.g.: benches to move between bathtub and toilet bowl (Fig.4), shower chairs, adjustable bathroom railings, special props to put under furniture which allow for easier getting up.

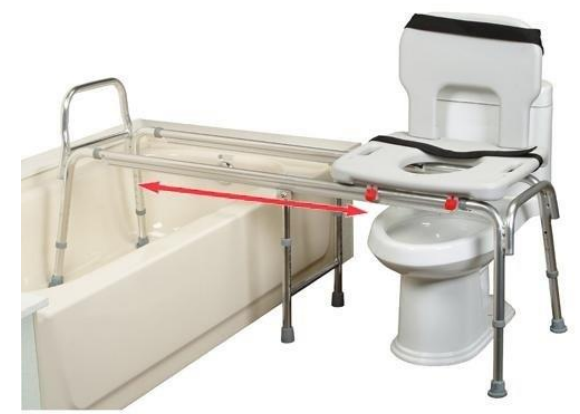

Fig. 4. Bench to move between bathtub and toilet bowl 
The feeling of comfort and keeping the intimacy causes that the most significant development of AAL facilities involves sanitary rooms. Apart from support facilities it is also necessary to design the rooms adequately: without barriers, steps, ensuring the freedom of movement. Sanitary fittings should be designed in a way that the toilet bowl could have a raised toilet seat that would enable the elderly easier rising up, gripping the handle and getting back on their feet. Minimizing the risk of slipping in the bathroom is a crucial issue. Bathroom is, according to the statistics, the place at home where the most accidents happen. To prevent that it is advisable to use walk-in bathtubs (Fig.5) and walk-in showers equipped with easy to grip handles and non-slip surfaces.

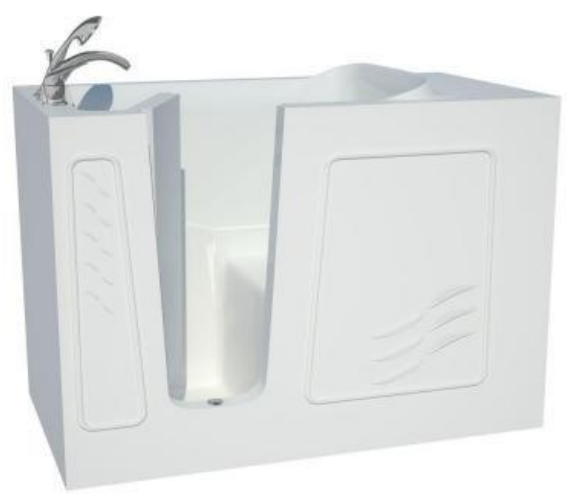

Fig. 5 Walk-in bathtub

\section{CONCLUSION}

The problem of aging society present in Japan and countries of Western Europe will be a tremendous challenge to designers and producers of construction and sanitary products also in our country. The demographic change will cause the necessity of adjusting the existing buildings as well as the newly designed ones to new requirements. It is necessary to update the norms concerning the technical and construction conditions of the buildings as well as research the influence of bigger share of elderly persons in society on requirements set on buildings. A substantial share of current buildings in which elderly persons live was designed in the 1950's, 60's and 70's under norms of that time. It effects in many communicational and utilitarian inconveniences for current dwellers because of e.g. narrow corridors in the flats, cramped 
bathrooms with limited safe movement capabilities and kitchens needing adaptation for persons with wheelchairs. Additionally, frequent lack of ability to redevelop complicates things substantially. It arises from the fact that a big share of residential buildings is designed and constructed based on prefabricates. The walls which are an impediment to movement frequently cannot be demolished due to being load-bearing. This situation requires working on alternative systems which will be able to fulfill the users' needs without interference into static safety of the construction. Apart from improving communication inside the buildings, the need to a thorough improvement of communicational and functional availability of the surroundings also arises. It includes the improvement of driveways to the buildings and entrances, removal of redundant curbs, barriers, widening the sidewalks. Despite a substantial improvement in this respect in the last 10-15 years, still a lot of housing estates built in the past century does not fulfill the requirements of safe movement of the disabled and elderly. In many cases associated with widening the sidewalks lack of action by housing cooperatives is connected to lack of funds and strict regulations concerning parking spaces for increasing amount of cars. Unfortunately, financial as well as spatial and technological considerations very frequently impair building underground garages. The solution of aforementioned problems will be an operation expected to take a long time. It will also require cooperation from numerous social groups such as construction engineers, sanitary engineers and town planners. 


\section{REFERENCES}

1. Bock T., Georgoulas C., and Linner T. "Towards Robotic Assisted Hygienic Services: Concept for Assisting and Automating Daily Activities in the Bathroom". Gerontechnology 2012; 11(2):362.

2. Bookman, A., Harrington, M., Pass, L., Reisner, E., Family Caregiver Handbook, Cambridge, MA: Massachusetts Institute of Technology, 2007.

3. Budny J., „Dostosowanie budynków użyteczności publicznej - teoria i narzędzia”. Biblioteczka dla osób niepełnosprawnych. Stowarzyszenie Przyjaciół Integracji. Warszawa, 2009.

4. Cohen, J.E., "Human Population: The Next Half Century". Science, Vol. 302(5648), pp. 1172-1175, 2003.

5. McDowell, I., Newell, C., Measuring Health: A Guide to Rating Scales and Questionnaires, 2nd edition, New York: Oxford University Press, 1996.

6. Główny Urząd Statystyczny, "Prognoza ludności na lata 2014-2050". Studia i Analizy Statystyczne. Warszawa, 2014.

7. Kotowska I.E., Jóźwiak J., „Nowa demografia Europy”. Roczniki Kolegium Analiz Ekonomicznych, Zeszyt 28/2012.

8. M. Książek, P. Nowak, S. Kivrak, J. Rosłon, L. Ustinovichius, "Computer-aided decision-making in construction project development", Journal of Civil Engineering and Management, vol. 21, is. 2, 2015, pp. 248-259.

9. M. Książek, P. Nowak, J. Rosłon, T. Wieczorek, "Multicriteria assessment of selected solutions for the building structural walls", 23rd Russian-Polish-Slovak Seminar on Theoretical Foundation of Civil Engineering, TFoCE 2014, Wroclaw, Szklarska Poreba; Poland; 25 August 2014 through 29 August 2014, Procedia Engineering, Vol. 91, 2014, 406-411.

10. M. Książek, P. Ciechowicz, "Selection of the general contractor using the AHP method", Archives of Civil Engineering, vol. LXII, is. 3, 2016, pp. 105-116.

11. E. Radziszewska-Zielina, B. Szewczyk, "Controlling partnering relations in construction operations using fuzzy reasoning”, Archives of Civil Engineering, vol. LXI, is. 3, 2015, pp. 89-104.

12. E. Radziszewska-Zielina, "Fuzzy control of the partnering relations of a construction enterprise", Journal of Civil Engineering and Management, Vol. 17, No. 1, 2011, pp. 5-15.

13. E. Radziszewska-Zielina, "Analysis of the partnering relations of Polish", Slovak and Ukrainian construction enterprises, „Technological and Economic Development of Economy”, Vol. 16, No. 3, 2010, pp. 432-454.

14. E. Radziszewska-Zielina, "Analysis of the Impact of the Level of Partnering Relations on the Selected Indexes of Success of Polish Construction Enterprises”, Inzinerine Ekonomika-Engineering Economics, Vol. 21, No. 3, 2010, pp. 324-335.

15. E. Radziszewska-Zielina, "The Application of Multi-Criteria Analysis in the Evaluation of Partnering Relations and the Selection of a Construction Company for the Purposes of Cooperation", Archives of Civil Engineering, vol. LXII, is. 2, 2016, pp. 167-182.

16. J. Korytarova, T. Hanak, R. Kozik, E. Radziszewska-Zielina, “Exploring the contractors' qualification process in public works contracts", Procedia Engineering, Elsevier, vol. 123, 2015, pp. 276-283.

17. Wiener, J.M., Hanley, R.J., Clark, R., Van Nostra, J.F., "Measuring the Activities of Daily Living: Comparisons Across National Surveys". Journal of Ger-ontology, Vol. 45(6), pp. 229-237, 1990. 


\section{LIST OF FIGURES AND TABLES:}

Fig. 1. Range of vertical and horizontal arm movement.

Rys. 1. Zasięg ruchu rąk w pionie i poziomie.

Fig. 2. Basic dimensional parameters of a bathroom.

Rys. 2. Podstawowe parametry wymiarowe łazienki.

Fig. 3. Care dependency vs. age groups.

Rys. 3. Potrzeba opieki w zależności od wieku osób.

Fig. 4. Bench to move between bathtub and toilet bowl.

Ławka do przemieszczania się pomiędzy wanną a muszlą toaletową.

Rys. 4. Ławka do przemieszczania się pomiędzy wanną a muszlą toaletową.

Fig. 5. Walk-in bathtub.

Rys. 5. Niskoprogowa wanna dla osób starszych. 


\section{WYBRANE ROZWIĄZANIA PROJEKTOWE W BUDOWNICTWIE STOSOWANE DLA POTRZEB OSÓB STARSZYCH I NIEPELNOSPRAWNYCH W POLSCE}

Slowa kluczowe: ambient assisted living, osoby starsze, budownictwo, demografia

\section{STRESZCZENIE:}

Niniejszy artykuł porusza zagadnienie procesu starzenie się społeczeństwa i wpływu tego zjawiska na projektowanie i wykonywanie obiektów budowlanych w Polsce oraz adaptacje obecnie istniejących budynków dla potrzeb osób niepełnosprawnych i starszych.

Zagadnienie to nabrało szczególnego znaczenia w naszym kraju w szczególności po 1989 roku, kiedy to tendencje w obszarze zmiany w zakresie ruchu naturalnego doprowadziły do istotnych zmian w strukturze demograficznej kraju. W wyniku znaczącej poprawy warunków socjalno-bytowych bardzo korzystnym zmianom uległa długość życia społeczeństwa. Podobnie, jak większość krajów wysokorozwiniętych z Europy Zachodniej, także w Polsce zauważony został problem związany z niską dzietnością społeczeństwa oraz z obniżeniem liczby zachowań dotyczących tworzenia i trwałości związków małżeńskich. Otworzenie się granic w Europie, a w szczególności brak barier w podejmowaniu pracy zawodowej w wielu krajach Europy Zachodniej spotęgował zjawisko migracji zagranicznych. Dodatkowo Polska wpisała się w tzw. procesy ludnościowe, które definiuje się jako drugie przejście demograficzne charakteryzujące się tworzeniem rodzin w późnym wieku, relatywnie późnym okresem macierzyństwa, spadkiem liczby małżeństw oraz wzrostem liczby związków nieformalnych. Procesy te obserwowane są w Europie od połowy lat 60-tych i obecnie posiadają już charakter globalny. Wprowadzone w 2003 roku przez D. van de Kaa pojęcie „Nowa demografia Europy” oznacza nie tylko zmiany towarzyszące procesom przejścia do nowoczesnej reprodukcji, lecz utrwalenie się tego procesu znacznie poniżej prostej zastępowalności pokoleń.

W artykule przedstawiono ponadto bieżące trendy dotyczące rozwoju ludności w Polsce oraz prawdopodobne perspektywy na kolejne 45 lat, w których niska płodność (współczynnik dzietności równy 1,5 i mniej) wraz z systematycznym wydłużaniem długości życia oraz wzrostem znaczenia migracji prowadzić będzie do zmniejszenia przyrostu naturalnego, a w konsekwencji do nieodwracalnych zmian struktury populacji. Konsekwencją tego będzie zachwianie relacji pomiędzy generacjami - osobami w wieku produkcyjnym oraz osobami starszymi. Prognozy zauważono już w latach 80-tych i 90-tych XX. wieku, a sposobem na ich minimalizowanie były propozycje wydłużenia wieku przejścia ludności w okres pobierania świadczeń emerytalnych oraz pobudzenie aktywności zawodowej osób w wieku +50 i +60 lat. Badania naukowe prowadzone obecnie na świecie dowodzą, że udział osób w wieku $65+$ wzrośnie z 7\% w pierwszej dekadzie XXI. wieku, do 16\% w 2050 roku. Pomimo faktu, że na tle Unii Europejskiej Polska jest nadal stosunkowo młodym krajem, $\mathrm{z}$ medianą wieku wynoszącą w 2012 roku $-38,7$ lat, $\mathrm{z}$ dużym prawdopodobieństwem można stwierdzić, że tendencje starzenia się społeczeństwa są nieodwracalne.

Zgodnie z najnowszą prognozą Eurostatu (EuroPop 2013), po 2024 roku udział osób w wieku +65, w ogólnej strukturze Polski przekroczy $20 \%$, osiągając wartość 33\% w roku 2060. Konsekwencją tych zjawisk będzie zwiększenie obciążeń podatkowych osób czynnych zawodowo oraz prawdopodobne zmniejszenie wydajności ekonomicznej systemów emerytalnych. W dalszej kolejności zauważalne będzie zubożenie osób w okresie emerytalnym oraz zmniejszenie liczby osób młodych, jak również w wieku średnim, mogących podjąć opiekę nad osobami starszymi. Dodatkowo niepewna sytuacja gospodarcza, a także polityczna na obszarze Europy środkowo-wschodniej podaje pod wątpliwość 
możliwość otwarcia granic na wschodzie Polski i wzrost migracji zarobkowej, mogący przyczynić się do poprawy sytuacji.

Mając na uwadze powyższe stwierdzenia należy podjąć próbę rozwiązania problemu starzejącego się społeczeństwa poprzez rozwój i wdrażanie koncepcji ułatwiających prowadzenie przez osoby starsze codziennych czynności życiowych, w szczególności zwiększających ich autonomię, mobilność i samodzielność. Autor przedstawił w tym celu, obecny stan prawny w zakresie przepisów i regulacji odnoszących się do aspektów dostosowywania budynków i ich części na potrzeby osób niepełnosprawnych. Dodatkowo opisane zostały wymiary i zakresy ruchu dla osób niepełnosprawnych oraz podstawowe wymagania funkcjonalne i użytkowe dla łazienek. W kolejnym rozdziale zaprezentowano koncepcję Ambient Assisted Living ,życie wspierane przez otoczenie” wraz z przykładami urządzeń sanitarnych do zastosowania w budynkach mieszkalnych.

Analizując regulacje prawne w naszym kraju w zakresie dostosowywania obiektów budowlanych dla osób starszych, należy stwierdzić, że zachodzi potrzeba bardzo dużych zmian w zakresie dostosowania rozwiązań technicznych dla potrzeb osób w podeszłym wieku oraz osób niepełnosprawnych. Przedstawione w niniejszym artykule trendy dotyczące rozwoju ludnościowego kraju w sposób jasny obrazują bardzo szybką potrzebę działania w tym zakresie. Zdaniem Autora osiągniecie pozytywnych rezultatów wymagać będzie szerokiej współpracy wielu specjalistów, począwszy od planistów, urbanistów, poprzez inżynierów budownictwa, a skończywszy na pracownikach administracji państwowej, naukowcach oraz politykach. Brak szybkich działań w niniejszej sprawie spowodować może znaczące pogorszenie poziomu życia osób starszych, oraz wiążące się z tym trudności społeczno-finansowe dla reszty społeczeństwa.

Prawdopodobne ograniczenie subwencji i środków pomocowych z Unii Europejskiej dla Polski, które może nastąpić po 2020 roku, spowoduje pogłębienie się problemu wydajności ekonomicznej państwa, w tym także systemów emerytalnych. Co gorsza dla systemu emerytalnego, w przeciągu najbliższych 5 lat, w okres pobierania świadczeń emerytalnych wchodzić będę osoby urodzone w latach 1950-1955, które pochodzą z tzw. „wyżu powojennego”, co skutkować będzie koniecznością wypłat bardzo dużej liczby świadczeń dla tych właśnie osób. 